\title{
Trace elements and cathodoluminescence of detrital quartz in Arctic marine sediments - a new ice-rafted debris provenance proxy
}

\author{
A. Müller ${ }^{1,2}$ and J. Knies ${ }^{1,3}$ \\ ${ }^{1}$ Geological Survey of Norway, 7491 Trondheim, Norway \\ ${ }^{2}$ Natural History Museum of London, London SW7 5BD, UK \\ ${ }^{3}$ Centre for Arctic Gas Hydrate, Environment and Climate, University of Troms $\varnothing, 9037$ Troms $\varnothing$, Norway
}

Correspondence to: A. Müller (axel.muller@ngu.no)

Received: 3 July 2013 - Published in Clim. Past Discuss.: 24 July 2013

Revised: 5 October 2013 - Accepted: 22 October 2013 - Published: 20 November 2013

\begin{abstract}
The records of ice-rafted debris (IRD) provenance in the North Atlantic-Barents Sea allow the reconstruction of the spatial and temporal changes of ice-flow drainage patterns during glacial and deglacial periods. In this study a new approach to characterization of the provenance of detrital quartz grains in the fraction $>500 \mu \mathrm{m}$ of marine sediments offshore of Spitsbergen is introduced, utilizing scanning electron microscope backscattered electron and cathodoluminescence (CL) imaging, combined with laser ablation inductively coupled plasma mass spectrometry. Based on their micro-inclusions, $\mathrm{CL}$ and trace element characteristics, the investigated IRD grains can be classified into five distinct populations. Three of the populations are indicative of potential IRD provenance provinces in the Storfjord area including Barentsøya and Edgeøya. The results imply that under modern (interglacial) conditions IRD deposition along the western Spitsbergen margin is mainly governed by the East Spitsbergen Current controlling the ice-drift pattern. The presence of detrital quartz from local provinces, however, indicates that variations in IRD supply from western Spitsbergen may be quantified as well. In this pilot study it is demonstrated that this new approach applied on Arctic continental margin sediments bears a considerable potential for the definition of the sources of IRD and thus of spatial/temporal changes in ice-flow drainage patterns during glacial/interglacial cycles.
\end{abstract}

\section{Introduction}

Provenance studies of ice-rafted debris (IRD) in the North Atlantic-Barents Sea are a remarkable tool for providing insights into the dynamics of large ice sheets and the timing and duration of their disintegration (e.g. Hemming, 2004 for a review). Prominent IRD layers in the North Atlantic - the sedimentological expression of ice-sheet surging during a Heinrich event - and their origins illustrate the complexity of icesheet-ocean interactions in the Northern Hemisphere during the last glacial period (e.g. Kolla et al., 1979; Grousset et al., 1993; Bond et al., 1997, 2001; Farmer et al., 2003; Peck et al., 2007; Andrews et al., 2009; Verplanck et al., 2009).

Identifying the provenance of such IRD layers in the Arctic is, however, not straightforward because of the abundance of IRD from both sea ice and glacial rafting (Stein, 2008, for review). For instance, the provenance of IRD-rich sediments along the Spitsbergen continental margin has been constrained by various approaches including bulk/clay mineralogy (Elverhøi et al., 1995; Andersen et al., 1996; Vogt et al., 2001; Forwick et al., 2010), petrography of dropstones (> $500 \mu \mathrm{m}$ ) (Bischof, 1994; Hebbeln et al., 1994, 1998), iron grain chemical fingerprinting (Darby et al., 2002) and stable isotope geochemistry (Sr, Nd) (Tütken et al., 2002). The results of all studies have demonstrated their potential to provide insights into both the changing sea ice drift patterns in the Arctic Ocean and the complex Eurasian ice-sheet history during the Quaternary. The application of these provenance proxies is particularly relevant for identifying large-scale geological provinces and thus circum-North Atlantic/Arctic ice sheet dynamics and sea ice patterns. However, they are 
limited to pin point the exact bedrock formation onshore and consequently delineating material derived through glacial erosion, transport, and deposition from individual ice stream (ice sheet) dynamics over time.

In the present study, we focus on detrital quartz grains in the $>500 \mu \mathrm{m}$ fraction of marine sediments offshore of Spitsbergen considered to be IRD derived from melting icebergs and sea ice (cf. Elverhøi et al., 1995; Hebbeln et al., 1998). Potential source rocks for specific bedrock formations are constrained by introducing a new analytical approach combining structural studies of quartz grains by optical microscopy, scanning electron microscope backscattered electron imaging (SEM-BSE), scanning electron microscope cathodoluminescence (SEM-CL) imaging with chemical analyses of quartz grains by laser ablation inductively coupled plasma mass spectrometry (LA-ICP-MS). Quartz is a mineral preferred for provenance studies due to its resistance to weathering and common presence in rocks and soils. The structural analysis of detrital quartz grains in sedimentary rocks by means of optical microscopy and SEM-CL has a long history in provenance evaluation in sedimentology (e.g. Seyedolali et al., 1997; Götze and Zimmerle, 2000, and references therein). Recent developments of microbeam techniques, such as LA-ICP-MS and secondary ion mass spectrometry, enable the chemical characterization of quartz grains down to $\sim 100 \mu \mathrm{m}$ in size. Chemical analyses have shown that the trace element signature of quartz is controlled by the physicochemical conditions of quartz formation (e.g. Götze, 2009, and references therein) and, thus, represents a geochemical fingerprint of the quartz origin. However, the chemical characterization of quartz grains by these analytical techniques has not been applied for provenance studies so far.

Up to now, we have studied 9 core-top $(0-1 \mathrm{~cm})$ samples randomly distributed along the western and southern coast of Spitsbergen (Fig. 1) and compared the quartz properties in the $>500 \mu \mathrm{m}$ fraction with 18 onshore samples from potential source areas in central, west, south and southeast Spitsbergen. Our results show that various bedrock provinces in the study area are identifiable in the quartz grains offshore of Spitsbergen. Long-distance transport by sea ice is the dominant transport mechanism for the quartz grains. In addition, quartz grains released from melting icebergs/sea ice, originating from either central or southeastern Spitsbergen, are clearly recognized. Considering the complicated glacial dynamics of former Barents Sea ice sheets as recently outlined by Dowdeswell et al. (2010), this new approach applied to Arctic continental margin sediments will help to define the sources of IRD and thus spatial/temporal changes in ice-flow drainage patterns better.

\section{Physiogeographic setting}

\subsection{Geology}

Spitsbergen, the main island of the Svalbard archipelago east of the Fram Strait, forms the northwestern edge of the Barents Sea (Fig. 1a). Its geological range provides an almost complete succession from Precambrian to Quaternary strata (Steel and Worsley, 1984; Dallmann, 1999). Precambrian metamorphic crystalline rocks of the Hecla Hoek group and sand/siltstones of Devonian ages prevail in the northern and northwestern part. Nearly undisturbed strata of Mesozoic sedimentary rocks dominate the central and southern parts of the island, while Tertiary organic-rich siliciclastic rocks with coal seams dominate the inner part of southern Spitsbergen (Michelsen and Khorasani, 1991). The sea floor in the northwestern Barents Sea consists of Pleistocene moraines and of Holocene deposits including reworked morainic material (Dibner et al., 1970; Bjørlykke and Elverhøi, 1975). Geophysical data indicate the presence of Mesozoic sediments immediately below the Pleistocene cover (Sundvor, 1974).

\subsection{Oceanography}

The North Atlantic drift carries warm and saline Atlantic water northwards. One of its main branches (i.e. the West Spitsbergen Current (WSC) (Fig. 1b)) is defined by having temperatures $>2{ }^{\circ} \mathrm{C}$ and salinities $>34.9$ psu (Schlichtholz and Goszczko, 2006). Separated by the polar front, colder $\left(T<0{ }^{\circ} \mathrm{C}\right.$ and salinity $\left.<34.4 \mathrm{psu}\right)$ and ice-covered Arctic waters cross the northern Barents Sea and join the East Spitsbergen Current (ESC) (Fig. 1b). The ESC flows southward along the SE coast of Spitsbergen and transports cold water from the Arctic Ocean, which mixes with ambient water including freshwater outflow from fjords as it continues northward along the continental shelf off Spitsbergen (Skogseth, 2003). The density barrier separates the warm, saline Atlantic water from the relatively cold, fresh Arctic water on the shelf. The frontal region prevents intrusions of warm Atlantic water into the shelf and fjord region during winter. During winter (January-March) the ice edge in the Barents Sea achieves its maximum southward extent. This zone where the ice edge is most frequently located during spring is referred to as the marginal ice zone. Because the marginal ice zone is topographically trapped, its location during maximum extent is fairly constant being located near the $250 \mathrm{~m}$ isobaths north of the Bjørnøya and Hopen troughs (Fig. 1b) (Loeng, 1991). During the winter months of the sampling year 2001, the south and west coasts of Spitsbergen were regularly covered by drift ice (Fig. 2).

\subsection{Modern depositional environment}

The sedimentary environments of the sample locations have been characterized by sea floor photographs taken with the remotely operated vehicle (ROV "sprint 103") (Fig. 3) 


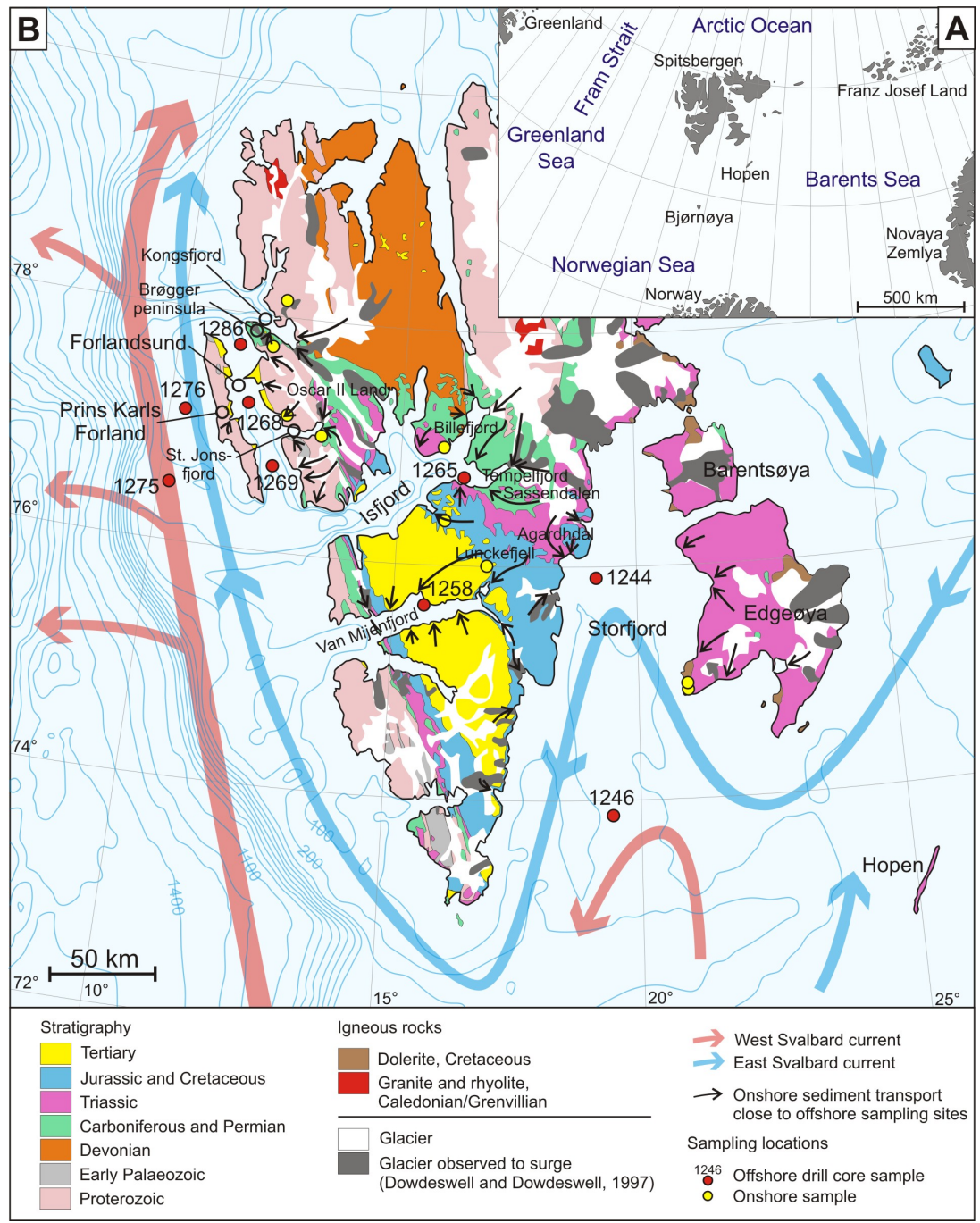

Fig. 1. (A) Location of Spitsbergen between the Greenland Sea, Barents Sea, Norwegian Sea and Arctic Ocean. (B) Simplified geological map of Spitsbergen according to Dallmann et al. (2002) with locations of offshore drill core samples (red dots) and onshore rock samples (yellow dots) and onshore sediment transport close to offshore sample locations (small black arrows). In addition, the map shows the East and West Spitsbergen currents and the distribution of surging glaciers according to Dowdeswell and Dowdeswell (1997).

(Winkelmann and Knies, 2005). The environments are classified into three different settings: (A) a high energy-no accumulation environment on the outer shelf/shelf break and bathymetric highs, (B) a low energy-high accumulation environment in the inner fjords and (C) a mixed type of moderate or variable energy-low accumulation environment of the transitional sites and the Barents Sea. Especially the winnowed lag deposits on the outer shelf (Setting A) are considered to represent erosional surfaces probably induced by contour or bottom currents (Andruleit et al., 1996). The "icerafted debris (IRD) - signal" of these hard ground surfaces may not reflect recent ice rafting but washing out of finer sediments. The onset of increased along-shelf bottom currents was dated to approximately $2.6 \mathrm{kyr}$ BP (Andruleit et al., 1996). The winnowing facies is observed on the shelf to water depth $>130 \mathrm{~m}$ b.s.f. west of Prins Karls Forland. Towards the incisions of the fjord systems (Setting B), areas are sheltered from the bottom currents, and therefore sites favouring deposition of modern ice-rafting. In contrast, the sediments from the Barents Sea shelf exhibit partly features of the higher energetic shelf environments west of Spitsbergen (Setting C). Within the Atlantic water domain, strong bottom currents $\left(\sim 0.5 \mathrm{~m} \mathrm{~s}^{-1}\right.$, based on ROV observation) leave single ice-rafted boulder outstanding. However, resuspension, entrainment and lateral displacement of fine-grained sediments seem to be not as dominant as on the shelf west of Spitsbergen. 


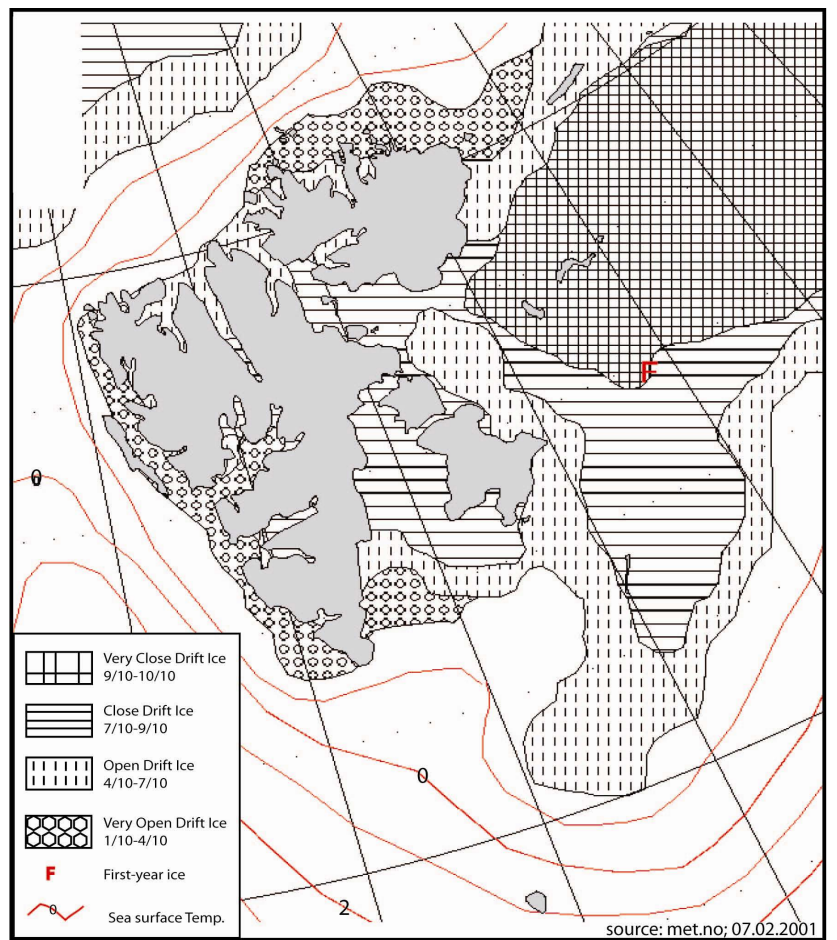

Fig. 2. Sea ice conditions around Spitsbergen on 7 February 2001, the year when the offshore drill core samples were taken (source: www.met.no).

\section{Materials}

\subsection{Offshore samples}

Nine short cores (length $30 \mathrm{~cm}$, diameter $11 \mathrm{~cm}$ ) have been collected west of Svalbard and on the adjacent shelf to the south on a scientific cruise with RV Heincke in summer 2001 (Fig. 1b). The short cores were taken with multicorer equipment. Undisturbed surfaces of all short cores (the upper first centimetre of the cores) were sampled and stored at $-20^{\circ} \mathrm{C}$ until analysis. Thereafter, all samples were freezedried and washed through $>500 \mu \mathrm{m}$ mesh with deionized water; 198 detrital quartz grains up to $3 \mathrm{~mm}$ in diameter were hand-picked from the $>500 \mu \mathrm{m}$ size fraction and embedded in epoxide resin and polished down half size for SEM and LA-ICP-MS analysis. The 198 grains represent all quartz grains $>500 \mu \mathrm{m}$ found in the available sample material. Samples were selected from two respective environmental settings (Table 1) including fossil ice rafting (> 2.6 kyr) (Setting A) and modern ice rafting (Setting B). Samples from the outer Barents Sea shelf (Setting C) have not been studied. The grain-size spectra in Setting B samples consist of sandbearing clayey silts, with sand contents varying between 0 and 6 wt. \% (Winkelmann, 2003). The sand content in Setting A samples may reach up to $30 \mathrm{wt} . \%$ of the total fraction. In the $>500 \mu \mathrm{m}$ fraction, the fraction of quartz relative to other minerals was between 10 and $20 \%$.

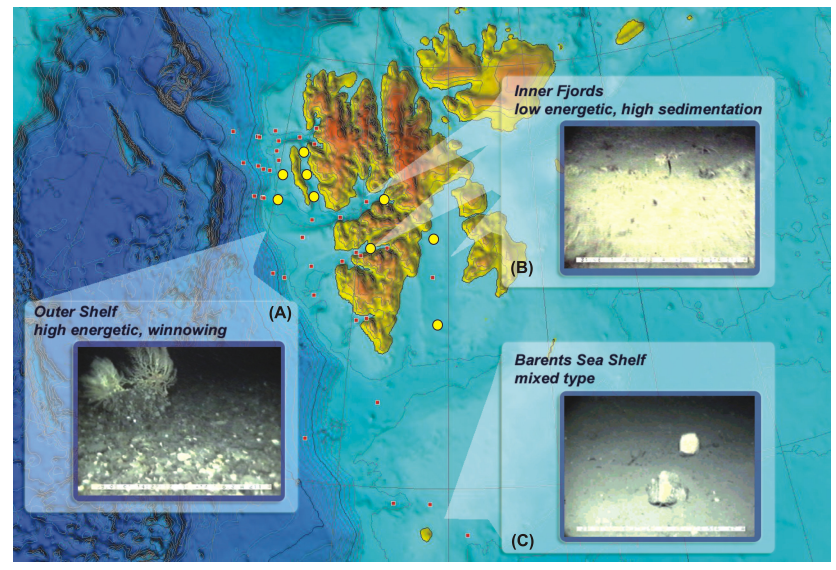

Fig. 3. Three types of sedimentary environment (modified after Winkelmann and Knies, 2005): (A) outer shelf, high energetic - no sedimentation; (B) inner fjords, low energetic - high sedimentation; (C) Barents Sea shelf, mixed type of medium energetic - low sedimentation (based on interpretation of ROV pictures). Yellow dots indicate the studied core-top samples. The small red squares mark samples studied by Winkelmann and Knies (2005).

\subsection{Onshore samples}

A total of 18 representative samples from Svalbard, including 4 quartzites, 2 hydrothermal quartz veins, 2 conglomerates, and 10 sandstones from potential provenance areas in central, west, south and southeast Spitsbergen, were studied in order to compare the quartz CL structures, micro inclusion inventory and chemistry with quartz grains of offshore samples (Fig. 1b, Table 2). The samples originate from archives of the Geological Survey of Norway (NGU) in Trondheim, University Centre in Svalbard (UNIS) $\mathrm{CO}_{2}$ Lab AS in Longyearbyen, the Norwegian Polar Institute (NPI) in Troms $\varnothing$, and the Store Norske Spitsbergen Grubekompani (SNSG) AS. Additional samples were collected during field work at Edgeøya in summer 2012 by colleagues from NGU and the UNIS $\mathrm{CO}_{2}$ Lab AS.

\section{Methods}

Mineral inclusions and intergrowths of non-quartz minerals occurring in some of the quartz grains were identified by optical microscopy and BSE imaging and were semi-quantitatively analysed using the LEO 1450VP SEM equipped with EDX detector at the Geological Survey of Norway in Trondheim. Different quartz populations and intra-granular microstructures, such as growth zoning, healed fractures, authigenic quartz overgrowths, were imaged using a Centaurus BS bialkali-type CL detector attached to the SEM.

LA-ICP-MS was applied for the in situ determination of the elements $\mathrm{Li}, \mathrm{Be}, \mathrm{Mn}, \mathrm{Ge}, \mathrm{Al}, \mathrm{Ti}$, and $\mathrm{Fe}$ in 133 out of 198 quartz grains; 65 grains were not analysed due to the 
Table 1. Studied sea-floor samples and environmental settings (see text for definition). The number of grains represent all quartz grains $>500 \mu \mathrm{m}$ which were found and investigated by optical microcopy, BSE and SEM-CL imaging. The numbers in parentheses indicate the number of LA-ICP-MS analyses.

\begin{tabular}{cccrcr}
\hline Sample & $\begin{array}{c}\text { Latitude } \\
{[\mathrm{N}]}\end{array}$ & $\begin{array}{c}\text { Longitude } \\
{[\mathrm{E}]}\end{array}$ & $\begin{array}{r}\text { Water } \\
\text { depth [m] }\end{array}$ & Setting & $\begin{array}{r}\text { No. of } \\
\text { grains }\end{array}$ \\
\hline 1244 & $77^{\circ} 56^{\prime}$ & $19^{\circ} 09^{\prime}$ & 96 & $\mathrm{~B}$ & $14(4)$ \\
1246 & $76^{\circ} 46^{\prime}$ & $19^{\circ} 25^{\prime}$ & 153 & $\mathrm{~B}$ & $16(8)$ \\
1258 & $77^{\circ} 49^{\prime}$ & $15^{\circ} 45^{\prime}$ & 43 & $\mathrm{~B}$ & $24(13)$ \\
1265 & $78^{\circ} 22^{\prime}$ & $16^{\circ} 22^{\prime}$ & 87 & $\mathrm{~B}$ & $8(5)$ \\
1268 & $78^{\circ} 37^{\prime}$ & $11^{\circ} 38^{\prime}$ & 102 & $\mathrm{~B}$ & $12(11)$ \\
1269 & $78^{\circ} 22^{\prime}$ & $12^{\circ} 19^{\prime}$ & 169 & $\mathrm{~B}$ & $14(10)$ \\
1275 & $78^{\circ} 15^{\prime}$ & $10^{\circ} 10^{\prime}$ & 297 & $\mathrm{~A}$ & $32(17)$ \\
1276 & $78^{\circ} 33^{\prime}$ & $10^{\circ} 19^{\prime}$ & 131 & $\mathrm{~A}$ & $34(27)$ \\
1286 & $78^{\circ} 52^{\prime}$ & $11^{\circ} 19^{\prime}$ & 159 & $\mathrm{~B}$ & $44(38)$ \\
\hline
\end{tabular}

high number of mineral and/or fluid inclusions which would contaminate the analyses. The ICP-MS used in this study is a double focusing sector field instrument (ELEMENT-1 Finnigan MAT) combined with a New Wave UP-193 nm excimer laser probe. Continuous raster ablation was carried out, resulting in ablated rasters of approximately $150 \times 100 \mu \mathrm{m}$ with depths of 20 to $30 \mu \mathrm{m}$. Element concentrations were calculated by multi-standard calibration. Limits of detection are listed in Tables S1 and S2. The analytical error ranges within $10 \%$ of the absolute concentration of the element. Detailed descriptions of the measurement procedures are given by Flem et al. (2002) and Flem and Müller (2012).

Processing and analysing the offshore (9) and onshore (18) samples with our new quantitative approach are relatively fast. For the LA-ICP-MS analyses (133 offshore quartz grains; 53 quartz grains in onshore samples), we used 20 working days including data processing. Initial hand-picking of 198 quartz grains, preparation of thick sections, investigations by optical microscopy and SEM and SEM-CL work lasted another ca. 30 working days. The analysis of ca. 100 samples to obtain information on the origin of IRDderived quartz grains in a millennial-centennial record outside Svalbard will last ca. 7 months with this new approach.

\section{Results}

\subsection{Characteristics of quartz grains in offshore samples}

The quartz grains of offshore samples were classified into five major types, A to E, based on mineral micro-inclusions, CL intensity, intra-granular structures visualized by SEM-CL imaging and trace element content (Fig. 4). The classification was developed by means of the observed, most significant features of the investigated offshore grains, and, thus, the classification application is restricted to the offshore sample area of this study. The distinguishing features were chosen in such a way that each offshore grain could be assigned to one group only. The characteristics of the five types can be described as follows.

Type A comprises monocrystalline, sub- to well-rounded, mineral-inclusion-free quartz grains $(0.4$ to $1.4 \mathrm{~mm})$ with no or very low CL signal. Type A grains are almost ubiquitous in every sampling area and form the major grain population (mean $48 \%$ ) of nearly all the samples except samples 1265 (Isfjord) and 1269 (Forlandsund; Figs. 4, 5). A number of these grains show cemented sericite and traces of $\mathrm{Fe}$ oxides/hydroxides at their surfaces, which are highlighted by black arrows in Fig. 4. These coatings represent remains of cement from eroded sandstone, and, thus, the A type grains are detrital quartz grains from eroded sandstones (secondary origin) (Table 3). The primary sources of the grains, before sedimentation as sandstones, were low-grade metamorphic quartzite and/or low-temperature hydrothermal segregation, facilitating the $\mathrm{CL}$ properties according to Bernet and Bassett (2005). Type A quartz commonly has low Ti $\left(<2.9 \mu \mathrm{gg}^{-1}\right)$, low $\mathrm{Li}\left(\leq 1.8 \mu \mathrm{gg}^{-1}\right)$, and variable $\mathrm{Al}\left(<8\right.$ to $221 \mu \mathrm{gg}^{-1}$; Table A1). Exceptions are three grains containing high $\mathrm{Li}$ (mean $110 \mu \mathrm{gg}^{-1}$ ) and $\mathrm{Al}$ (mean $2762 \mu \mathrm{gg}^{-1}$ ) (Fig. 6). Such high $\mathrm{Li}$ and $\mathrm{Al}$ concentrations have been described from hydrothermal quartz only (e.g. Jourdan et al., 2009). Ti concentrations $<2.9 \mu \mathrm{gg}^{-1}$ indicate quartz crystallization temperatures $<450{ }^{\circ} \mathrm{C}$ (Wark and Watson, 2006) implying lowgrade metamorphic and hydrothermal primary origin of A type grains (Table 3 ).

Type B grains are polycrystalline and polyphase quartz grains $(0.6$ to $3 \mathrm{~mm})$ with no or very low $\mathrm{CL}$ signal. The quartz is intergrown with $\mathrm{K}$-feldspar, mica (biotite and/or muscovite), chlorite, and calcite and contains microinclusions of apatite, pyrite, $\mathrm{Fe}$ oxides, calcite, dolomite, barite, rutile, zircon, and monazite. The group comprises $28 \%$ of the investigated grains. Type B grains are shown as BSE images in Fig. 4 in order to visualize their polyphase compositions. The quartz has low $\mathrm{Ti}\left(<2.9 \mu \mathrm{gg}^{-1}\right)$, low $\mathrm{Li}\left(\leq 2.8 \mu \mathrm{gg}^{-1}\right)$, and variable $\mathrm{Al}\left(<8\right.$ to $\left.344 \mu \mathrm{gg}^{-1}\right)$. The element concentrations are in the same range as for type A grains (Fig. 6). Like the type A grains, type B grains show microcrystalline remains of sericite and $\mathrm{Fe}$ oxides/hydroxides on the grain surfaces (see black arrows in Fig. 4) indicating that they are detrital grains from eroded sandstones (secondary origin). The primary sources of the type B grains are low-grade metamorphic quartzite (Table 3 ).

Type $\mathrm{C}$ represents a distinct quartz population comprising $7 \%$ of the grains investigated. The non-luminescent grains (0.6 to $1.2 \mathrm{~mm}$ ) are cut by thin, healed, brightly luminescent micro-fractures. Single grains of this type were found in almost all the sampled regions except Isfjord. Coatings of sericite and $\mathrm{Fe}$-oxides/hydroxides at the grain surfaces (see black arrow in Fig. 4) indicate that type C grains represent detrital grains from eroded sandstones (secondary origin) similar to type $\mathrm{A}$ and $\mathrm{B}$ grains. Type $\mathrm{C}$ grains have a consistent trace element content characterised by low $\mathrm{Li}$ (mean 
Table 2. Origin and type of investigated onshore samples for comparative studies. NGU - Geological Survey of Norway in Trondheim, NPI -

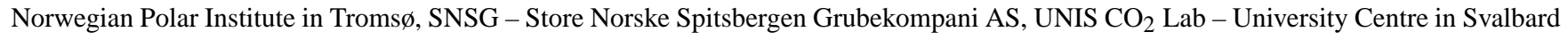
$\mathrm{CO}_{2} \mathrm{Lab}$ AS, Fm - Formation.

\begin{tabular}{|c|c|c|c|c|c|c|c|}
\hline Sample & Rock type & Area & Geological unit & Age & Latitude [N] & Longitude [E] & Sample archive \\
\hline YO85-269 & quartzite & $\begin{array}{l}\text { Brøgger } \\
\text { peninsula }\end{array}$ & $\begin{array}{l}\text { Kongsvegen } \\
\text { Group }\end{array}$ & Mesoproterozoic & $78^{\circ} 52^{\prime}$ & $12^{\circ} 06^{\prime}$ & NPI \\
\hline YO85-193 & quartzite & $\begin{array}{l}\text { Brøgger } \\
\text { peninsula }\end{array}$ & $\begin{array}{l}\text { Kongsvegen } \\
\text { Group }\end{array}$ & Mesoproterozoic & $78^{\circ} 52^{\prime}$ & $12^{\circ} 06^{\prime}$ & NPI \\
\hline YO85-Årat & quartzite & $\begin{array}{l}\text { Brøgger } \\
\text { peninsula }\end{array}$ & $\begin{array}{l}\text { Kongsvegen } \\
\text { Group }\end{array}$ & Mesoproterozoic & $78^{\circ} 52^{\prime}$ & $12^{\circ} 06^{\prime}$ & NPI \\
\hline $84-132$ & $\begin{array}{l}\text { hydrothermal } \\
\text { vein quartz in } \\
\text { biotite schist }\end{array}$ & Kongsfjord & $\begin{array}{l}\text { Krossfjorden } \\
\text { Group }\end{array}$ & Mesoproterozoic & $79^{\circ} 04^{\prime}$ & $12^{\circ} 16^{\prime}$ & NGU \\
\hline $31-50$ & $\begin{array}{l}\text { hydrothermal } \\
\text { vein quartz in } \\
\text { biotite schist }\end{array}$ & Kongsfjord & $\begin{array}{l}\text { Krossfjorden } \\
\text { Group }\end{array}$ & Mesoproterozoic & $79^{\circ} 04^{\prime}$ & $12^{\circ} 16^{\prime}$ & $\mathrm{NGU}$ \\
\hline WS79-8 & metagranite & Vestkysten & $?$ & Neoproterozoic? & $78^{\circ} 35^{\prime}$ & $12^{\circ} 19^{\prime}$ & NPI \\
\hline WS87-4 & conglomerate & St. Jonsfjord & $\begin{array}{l}\text { Gipsdalen } \\
\text { Group }\end{array}$ & $\begin{array}{l}\text { Late Carboniferous } \\
\text { to Early Permian }\end{array}$ & $78^{\circ} 32^{\prime}$ & $13^{\circ} 16^{\prime}$ & NPI \\
\hline WS87-25 & sandstone & St. Jonsfjord & $\begin{array}{l}\text { Gipsdalen } \\
\text { Group }\end{array}$ & $\begin{array}{l}\text { Late Carboniferous } \\
\text { to Early Permian }\end{array}$ & $78^{\circ} 29^{\prime}$ & $13^{\circ} 24^{\prime}$ & NPI \\
\hline MJ2 & chert pebble & $\begin{array}{l}\text { Billefjord } \\
\text { (N Isfjord) }\end{array}$ & $\begin{array}{l}\text { Gipsdalen } \\
\text { Group } \\
\text { Holtberget Fm }\end{array}$ & $\begin{array}{l}\text { Late Carboniferous } \\
\text { to Early Permian }\end{array}$ & $78^{\circ} 29^{\prime}$ & $15^{\circ} 57^{\prime}$ & SNSG \\
\hline AB $12-4$ & sandstone & Edgeøуa & $\begin{array}{l}\text { Kapp Toscana } \\
\text { Group } \\
\text { De Geerdalen } \\
\text { Fm }\end{array}$ & Late Triassic & $77^{\circ} 27^{\prime}$ & $20^{\circ} 50^{\prime}$ & UNIS $\mathrm{CO}_{2} \mathrm{Lab}$ \\
\hline AB12-16 & sandstone & Edgeøуa & $\begin{array}{l}\text { Kapp Toscana } \\
\text { Group } \\
\text { De Geerdalen } \\
\text { Fm }\end{array}$ & Late Triassic & $77^{\circ} 27^{\prime}$ & $20^{\circ} 57^{\prime}$ & UNIS $\mathrm{CO}_{2} \mathrm{Lab}$ \\
\hline PO1 & sandstone & Edgeøуа & $\begin{array}{l}\text { Kapp Toscana } \\
\text { Group } \\
\text { De Geerdalen } \\
\text { Fm }\end{array}$ & Late Triassic & $77^{\circ} 26^{\prime}$ & $20^{\circ} 52^{\prime}$ & $\mathrm{NGU}$ \\
\hline $\mathrm{PO} 2$ & sandstone & Edgeøya & $\begin{array}{l}\text { Kapp Toscana } \\
\text { Group } \\
\text { De Geerdalen } \\
\text { Fm }\end{array}$ & Late Triassic & $77^{\circ} 26^{\prime}$ & $20^{\circ} 52^{\prime}$ & $\mathrm{NGU}$ \\
\hline DH4 & sandstone & S Isfjord & $\begin{array}{l}\text { Kapp Toscana } \\
\text { Group Knor- } \\
\text { ringfjellet } \\
\text { Fm }\end{array}$ & $\begin{array}{l}\text { Late Triassic } \\
\text { to Early Jurassic }\end{array}$ & $78^{\circ} 12^{\prime}$ & $15^{\circ} 49^{\prime}$ & UNIS $\mathrm{CO}_{2} \mathrm{Lab}$ \\
\hline DH7A-1 & sandstone & S Isfjord & $\begin{array}{l}\text { Adventdalen } \\
\text { Group } \\
\text { Helvetiafjellet } \\
\text { Fm }\end{array}$ & Early Cretaceous & $78^{\circ} 12^{\prime}$ & $15^{\circ} 49^{\prime}$ & UNIS $\mathrm{CO}_{2} \mathrm{Lab}$ \\
\hline DH7A-2 & sandstone & S Isfjord & $\begin{array}{l}\text { Adventdalen } \\
\text { Group } \\
\text { Helvetiafjellet } \\
\text { Fm }\end{array}$ & Early Cretaceous & $78^{\circ} 12^{\prime}$ & $15^{\circ} 49^{\prime}$ & UNIS $\mathrm{CO}_{2} \mathrm{Lab}$ \\
\hline DH7A-3 & sandstone & S Isfjord & $\begin{array}{l}\text { Adventdalen } \\
\text { Group } \\
\text { Carolinefjellet } \\
\text { Fm }\end{array}$ & Early Cretaceous & $78^{\circ} 12^{\prime}$ & $15^{\circ} 49^{\prime}$ & UNIS $\mathrm{CO}_{2} \mathrm{Lab}$ \\
\hline MJ1 & conglomerate & Lunckefjell & $\begin{array}{l}\text { Van } \\
\text { Mijenfjorden } \\
\text { Group } \\
\text { Firkanten Fm }\end{array}$ & Tertiary & $78^{\circ} 00^{\prime}$ & $16^{\circ} 51^{\prime}$ & SNSG \\
\hline
\end{tabular}




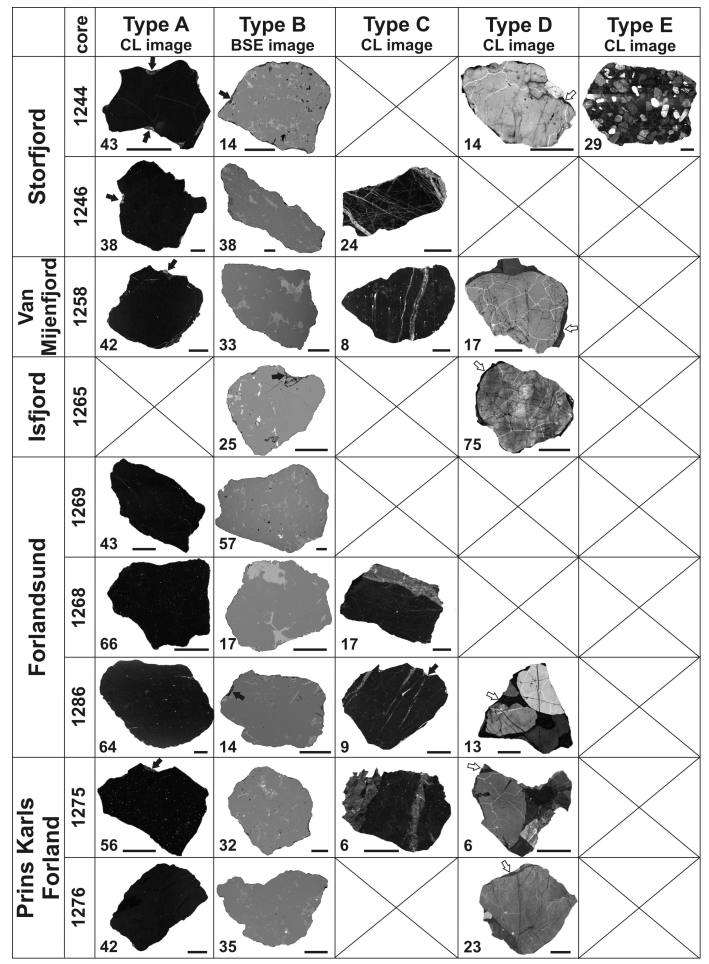

Fig. 4. Classification of quartz grains of the $>500 \mu \mathrm{m}$ size fraction according to their CL characteristics and micro-inclusion contents. Representative CL images of type A, C, D and E grains and BSE images of type B grains are shown. The numbers in the lower left of each cell indicate the percentage on the total number of quartz grains found. The scale bar length corresponds to $200 \mu \mathrm{m}$. The black arrows indicate remains of sericite cement at quartz grain edges and the white arrows remains of authigenic quartz.

Table 3. Suggested primary and secondary rock type origin of quartz grains in the $>500 \mu \mathrm{m}$ fraction of investigated offshore samples.

\begin{tabular}{lll}
\hline Grain type & $\begin{array}{l}\text { Primary origin } \\
\text { (prior to sedimentation as sandstone of } \\
\text { Carboniferous to Tertiary age) }\end{array}$ & $\begin{array}{l}\text { Secondary origin } \\
\text { (prior to Pleistocene to recent } \\
\text { marine sedimentation) }\end{array}$ \\
\hline A & $\begin{array}{l}\text { low-grade metamorphic quartzite and/or } \\
\text { hydrothermal segregation } \\
\text { low-grade metamorphic quartzite }\end{array}$ & $\begin{array}{l}\text { immature sandstones cemented by } \\
\text { sericite and Fe-oxides/hydroxides } \\
\text { immature sandstones cemented by } \\
\text { sericite and Fe-oxides/hydroxides } \\
\text { immature sandstones cemented by } \\
\text { sericite and Fe-oxides/hydroxides } \\
\text { mature sandstones cemented by } \\
\text { authigenic quartz } \\
\text { arkose cemented by authigenic quartz }\end{array}$ \\
C & $\begin{array}{l}\text { low-grade metamorphic quartzite and/or } \\
\text { hydrothermal segregation } \\
\text { plutonic or high-grade metamorphic rocks }\end{array}$ &
\end{tabular}

$1.4 \mu \mathrm{gg}^{-1}$ ) and moderate $\mathrm{Al}$ (mean $149 \mu \mathrm{gg}^{-1}$; Fig. 6). The CL properties and the trace element signature suggest that the type $\mathrm{C}$ grains are primarily erosion products of low-grade metamorphic quartzite and/or hydrothermal segregation or veins (primary origin) which were deposited in sandstones (Table 3).

Type D grains comprising $14 \%$ of the investigated samples are polycrystalline quartz fragments $(0.5$ to $1.5 \mathrm{~mm})$ consisting of rounded to well-rounded, partially broken detrital quartz grains with remains of authigenic quartz (see white arrows in Fig. 4). The detrital grains commonly have bright CL, and authigenic quartz is non-luminescent. The pore space of the sandstone fragments is completely filled by authigenic quartz. These fragments occur predominantly in Isfjord and to a lesser extent in Storfjord, Prins Karls Forland, Van Mijenfjorden and Forlandsund. The majority of the detrital grains show thin $(<5 \mu \mathrm{m})$, healed and non-luminescent micro-fractures which are characteristic of high-grade metamorphic and plutonic origin (e.g. Seyedolali et al., 1997). Moderate to high $\mathrm{Ti}$ concentrations (9.1 to $182.9 \mathrm{\mu gg}^{-1}$; 


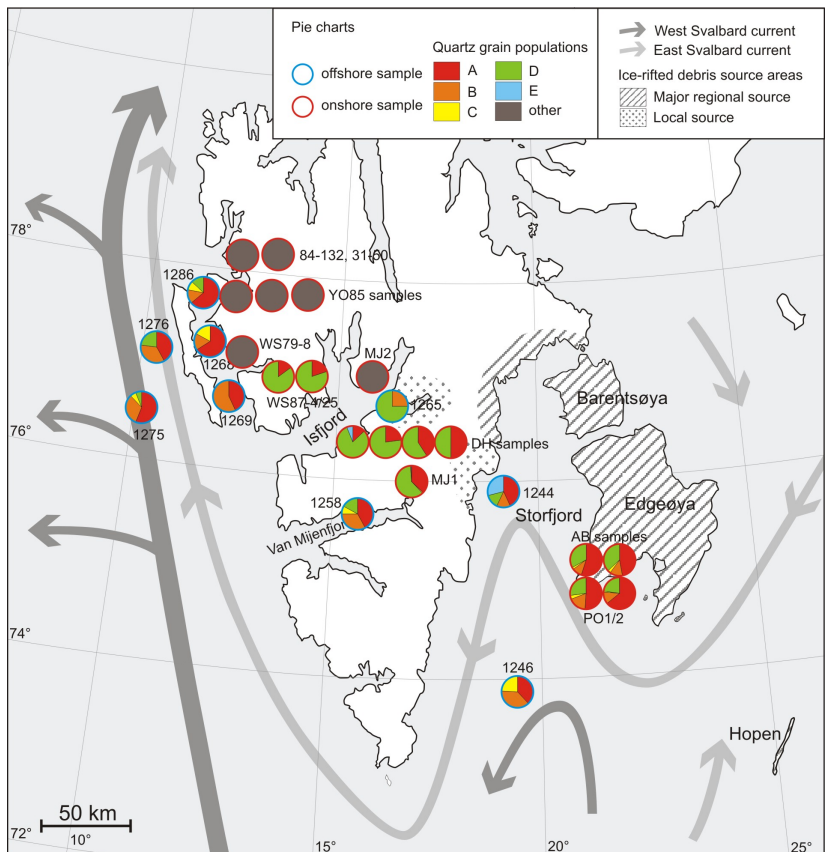

Fig. 5. Map of onshore and offshore samples of Spitsbergen and surrounding seas. Each pie chart represents the distribution of quartz grain populations (types A to E and "other"). The pie charts of offshore samples illustrate the dominance of type A an B grains in almost all samples, whereas the onshore samples have distinct quartz populations restricted to certain areas. The distribution of quartz populations in the Late Triassic sandstones from Edgeøya resemble most the distribution in offshore samples even though the precision of the percentage of offshore grain populations is poor due to the limited number of accessible grains.

Fig. 6) indicate minimum crystallisation temperatures of the detrital quartz from $523 \pm 9$ to $825 \pm 14^{\circ} \mathrm{C}$ (Wark and Watson, 2006), confirming the plutonic or high-grade metamorphic primary origin of the detrital quartz grains. The monomineral composition of the type $\mathrm{D}$ fragments and complete silicification of the pore space suggest that they originate from mature, coarse-grained sandstones (secondary origin, Table 3).

Type $\mathrm{E}$ grains comprise fine-grained arkose fragments ( 2 to $3 \mathrm{~mm}$ ) containing predominantly detrital rounded quartz grains and some K-feldspar grains cemented by nonluminescent authigenic quartz. Most of the detrital quartz grains exhibit moderate to bright CL intensity indicating plutonic or high-grade metamorphic primary origins. Type $\mathrm{E}$ is represented by four grains, found only in sample 1244 from inner Storfjord.

\subsection{Characteristics of quartz grains in onshore samples}

For comparison quartz grains in onshore rocks including sandstones, conglomerates, quartzite and hydrothermal quartz veins from the Brøgger peninsula, St. Jonsfjord,
Kongsfjord, Billefjord, Edgeøya, Isfjord, and Lunckefjell were examined and analysed (Table 2). The sample locations are indicated in Fig. 1b, and their stratigraphic origins are shown in Fig. 7. Where possible, the onshore quartz was assigned to one of the grain type groups defined by the offshore samples. However, a number of onshore samples contain quartz grains with features which were not observed in offshore grains. For these grains a classification was not necessary because they could immediately be excluded as the source of offshore grains.

The Proterozoic and Permo-Carboniferous onshore samples from the Brøgger peninsula, St. Jonsfjord and Kongsfjord are located in the glacier ice and river catchment areas of northern Forlandsund, relatively close to the offshore sample locations 1268,1269 , and 1286 . The quartz CL structures of the majority of these samples are different to those of the offshore grains. Quartz of samples 84-132, 31-50, YO85269 and WS79-8 has distinctive, lamella-like structures in CL (Fig. 8a), and quartz in sample YO-193 shows cloudy domains of bright luminescence within dull luminescent quartz (Fig. 8b). Sample YO85-Årat consists of quartz with moderate intense CL cross-cut by thin $(<5 \mu \mathrm{m})$, healed microfractures with bright CL similar to type $\mathrm{C}$ grains (Fig. 8c). However, the CL intensity and the Ti content $\left(5.2 \mu g^{-1}\right.$; Table S2) of the YO85-Årat quartz are significantly higher than those of the offshore type $\mathrm{C}$ grains. The sandstone and conglomerate of the Permo-Carboniferous Gipsdalen Group at St. Jonsfjord (WS87-4, WS87-25) contain 10 to $15 \%$ dull luminescent, featureless quartz grains corresponding to type $\mathrm{A}$ and 80 to $85 \%$ bright luminescent quartz grains with non-luminescent, healed micro-fractures similar to type D grains (Fig. 8d and e). The detrital grains are cemented by dull-luminescent authigenic quartz. However, the secondary structures of the type-D-like grains are more common in grains of the Gipsdalen sediments than in the offshore grains (compare Figs. 4 and 8d). Concentrations of $\mathrm{Al}, \mathrm{Ti}$ and $\mathrm{Li}$ plot in the same range as the offshore samples (Fig. 9). However, the proportion of grains with $\mathrm{Ti}>2.9 \mu^{-1} g^{-1}(42 \%)$ is significantly higher than in most of the offshore samples (Fig. 9a).

Sample MJ2 is a chert pebble from the PermoCarboniferous Gipsdalen Group at Billefjord close to offshore sample 1265 in the Isfjord. Chert is a common constituent of the Permo-Carboniferous sediments of Spitsbergen. In CL the sample shows a brecciated, moderate bright luminescent chert generation which is healed by a dull luminescent chert generation (Fig. 8f). Such structures have not been observed in the offshore grains. The chert has variable $\mathrm{Al}\left(81 \pm 63 \mu \mathrm{gg}^{-1}\right)$, high Fe (mean $\left.28 \pm 7 \mu \mathrm{gg}^{-1}\right)$ and no Ti (Table S2).

Four medium-grained sandstones (AB12-4, AB12-16, $\mathrm{PO} 1, \mathrm{PO} 2)$ from two different stratigraphic units of the Late Triassic De Geerdalen Formation at Edgeøya were investigated. The rocks of the De Geerdalen Formation cover more than $50 \%$ of the surface of Edgeøya and Barentsøya 

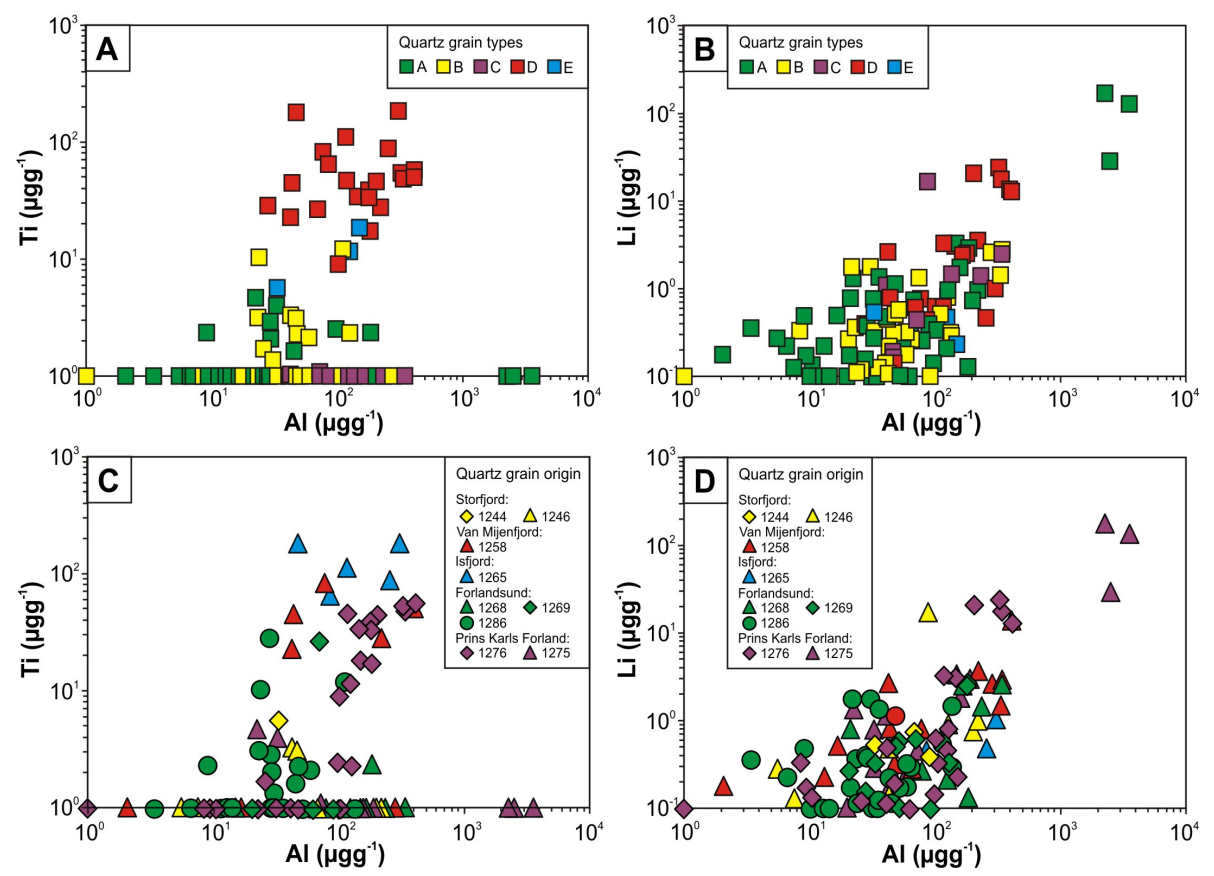

Fig. 6. Concentrations of $\mathrm{Al}$ versus $\mathrm{Ti}$ and $\mathrm{Li}$ of quartz grains in offshore samples. The same data are plotted, first, with respect to quartz type $(\mathbf{A}, \mathbf{B})$ and, second, to sample origin $(\mathbf{C}, \mathbf{D})$. (A, B) Type D grains have distinctively high Ti and relatively high average Al and Li compared to the grain types A, B, C, and E. (C, D) Samples 1265 (Isfjord), 1276 (Prins Karls Forland) and 1258 (Van Mijenfjorden) have relatively high proportions of grains with high Ti (D type grains).

and almost $100 \%$ of the island Hopen, which corresponds to more than $3000 \mathrm{~km}^{2}$ (Fig. 1). All sandstones are moderately sorted, containing $80-85 \%$ sub-angular quartz grains with an average grain size of $\sim 180 \mu \mathrm{m}(\mathrm{AB} 12-4, \mathrm{AB} 12-16)$ and $\sim 120 \mu \mathrm{m}$ (PO1, PO2), respectively (Fig. 10a). The cement consists of sericite, authigenic quartz and minor $\mathrm{Fe}$ oxides/hydroxides. Small (5 to $100 \mu \mathrm{m}$ ), euhedral authigenic quartz crystals occur in the interspace of the porous sandstone. The Edgeøya sandstones contain principally four types of quartz grains: (1) grains with dull, featureless CL corresponding to type A grains (47 to $64 \%$ ); (2) grains with dull, featureless $\mathrm{CL}$ and polyphase micro-inclusions, mostly mica similar to type B grains (10 to $18 \%$ ) (Fig. 10b); (3) dull luminescent grains with cross-cutting bright luminescent veins similar to type C grains (1 to $4 \%$ ); and (4) grains with bright $\mathrm{CL}$ and superimposing non-luminescent secondary structures corresponding to type $\mathrm{D}$ grains ( 27 to $34 \%$ ). Thus, the sandstones of the De Geerdalen Formation consist of the same quartz grain populations as most of the offshore samples. Even the grain type proportions of the Edgeøya sandstone and some offshore samples are comparable (1258, 1286; 1275, 1276) (Fig. 5).

Samples DH-4, DH7A-1, DH7A-2, and DH7A-3 are representative of medium- to coarse-grained Mesozoic sandstones from southern Isfjord (Table 2, Fig. 7). Mesozoic sediments cover about $30 \%$ of SW Spitsbergen (Fig. 1b). All sandstones are badly sorted with sericite cement. The sub- angular to rounded quartz grains comprise 80 to $100 \%$ of the grains in the sediments. Authigenic quartz is not developed. Between 13 and $50 \%$ of the quartz grains exhibit featureless CL with weak intensity corresponding to the CL characteristics of type A grains. The other population comprises quartz grains with bright $C L$ superimposed by dull luminescent thin $(<5 \mu \mathrm{m})$ veins corresponding to type D grains (Fig. 10c). The bright luminescent type $\mathrm{D}$ grains are characterized by high and variable average Ti of $76 \pm 80 \mathrm{\mu gg}^{-1}$ (Table S2; Fig. 9c). Sample DH7A-1 is the only investigated onshore sample which contains fragments of fine-grained arkose, which correspond to type $\mathrm{E}$ grains (Fig. 10d). Type $\mathrm{B}$ and $\mathrm{C}$ grains were not found.

The conglomerate MJ1 is a representative sample of the Tertiary Van Mijenfjorden Group from Lunckefjell. Tertiary sediments cover about $30 \%$ of SW Spitsbergen (Fig. 1b). Large quartz grains $(>1 \mathrm{~mm})$ are sub-rounded and small grains are sub-angular. The grains are cemented by weak luminescent authigenic quartz (Fig. 10e); $61 \%$ of the quartz grains have bright CL corresponding to the CL characteristics of type $\mathrm{D}$ grains. The other quartz grains have featureless $\mathrm{CL}$ with low intensity similar to type A grains. In addition, a few grains of chert were identified (Fig. 10f). 

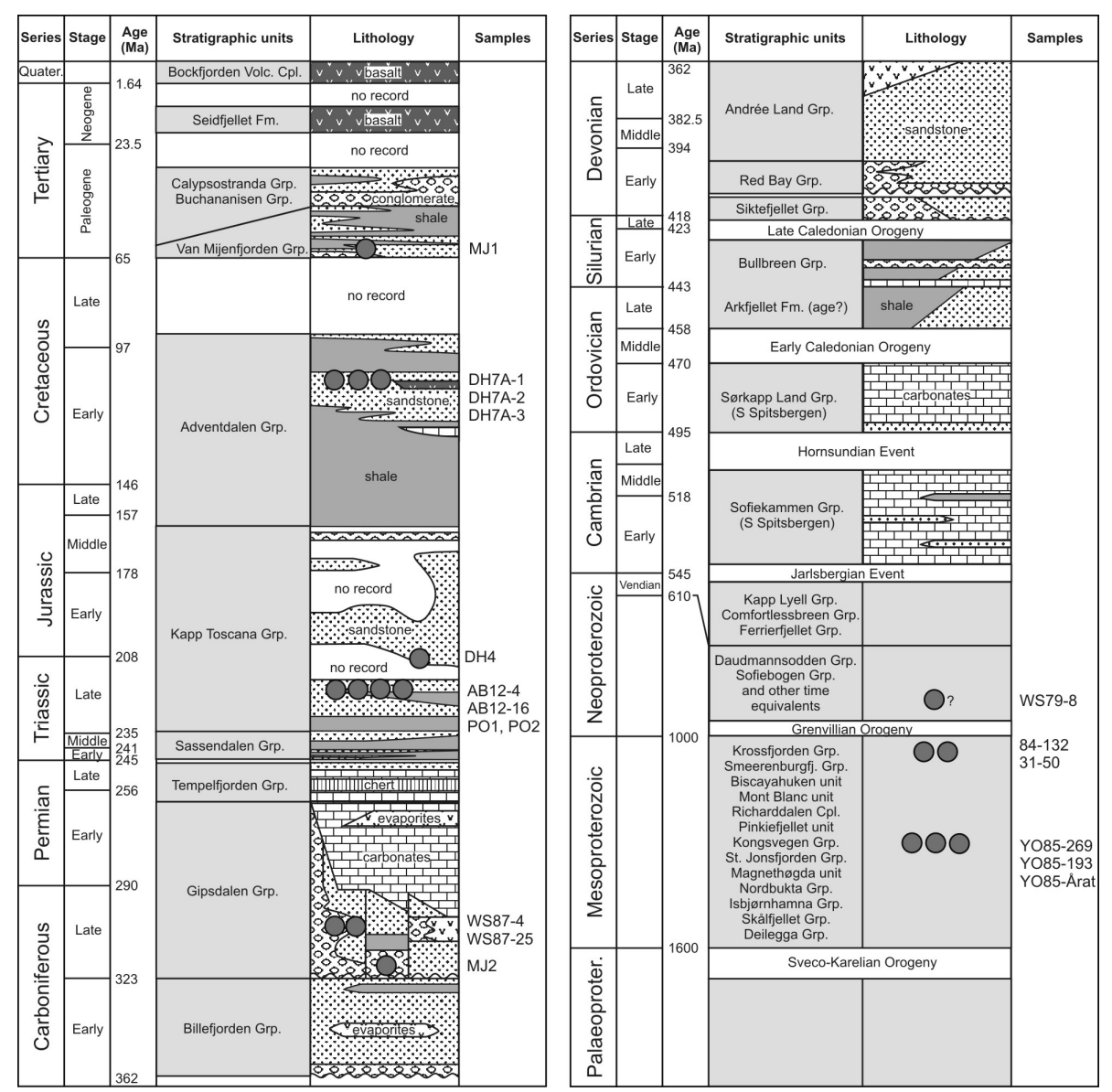

Fig. 7. Simplified geological timetable of Spitsbergen according to Dallmann (1999) and Dallmann et al. (2002) with stratigraphic positions of investigated onshore samples (dark circles).

\section{Discussion}

A and B type grains are ubiquitous in almost all offshore regions sampled and represent the major quartz-grain populations in the $>500 \mu \mathrm{m}$ size fraction (Figs. 4, 5). The homogeneity in frequency and regional distribution of the two grain populations suggests that the onshore rocks close to the offshore sampling sites do not serve as the main catchment areas. The onshore lithologies close to the offshore sample locations are either Proterozoic crystalline rocks (Oscar II Land east of Forlandsund, eastern Prins Karls Forland), Palaeozoic metamorphic rocks (western Prins Karls Forland), or Mesozoic to Cenozoic sedimentary rocks (Van Mijenfjorden, Isfjord and Storfjord) (Dallmann et al., 2002). The erosion of rocks of such diverse sedimentary and metamorphic histories would produce quartz grains with highly variable trace element concentrations and CL properties. Indeed, all investigated onshore samples east of Forlandsund contain quartz with CL features that are completely absent in the offshore grains (Fig. 8a-c). Further, different from the offshore grains type D quartz grains are the most dominant quartz population in all investigated sandstones north and south of Isfjord. Only in innermost Isfjord (sample 1265) close to the glacier ice and river catchment areas, significant proportion of type D quartz grains occurs in the $>500 \mu \mathrm{m}$ fraction. This implies that modern ice rafting in the Forlandsund area cannot be the result of local iceberg melting.

Similar frequency and prevalence of type A and B quartz grains are observed in Setting A ("fossil ice rafting") locations 1275 and 1276 outside Prins Karls Forland as well (Figs. 3, 5). These winnowed lag deposits are widely distributed on the shelf in water depth $>130 \mathrm{~m}$ (Winkelmann and Knies, 2005). The IRD most likely represents a mixture of debris released by melting sea ice and icebergs prior to $2.6 \mathrm{kyr}$ (Andruleit et al., 1996). The prevalence of type A and B grains in these "fossil" sediments suggest the same source for the quartz grains as for the modern ice-rafted material. It confirms the hypothesis that the onshore rocks close to the offshore sampling sites are not the main source and, thus, that the main catchment area is somewhere else.

Similar circumstances are postulated for type $\mathrm{C}$ grains. These occur in almost all sampled regions except Isfjord but form, in contrast to type A and B grains, a minor grain population. However, it appears that types A, B and C grains 

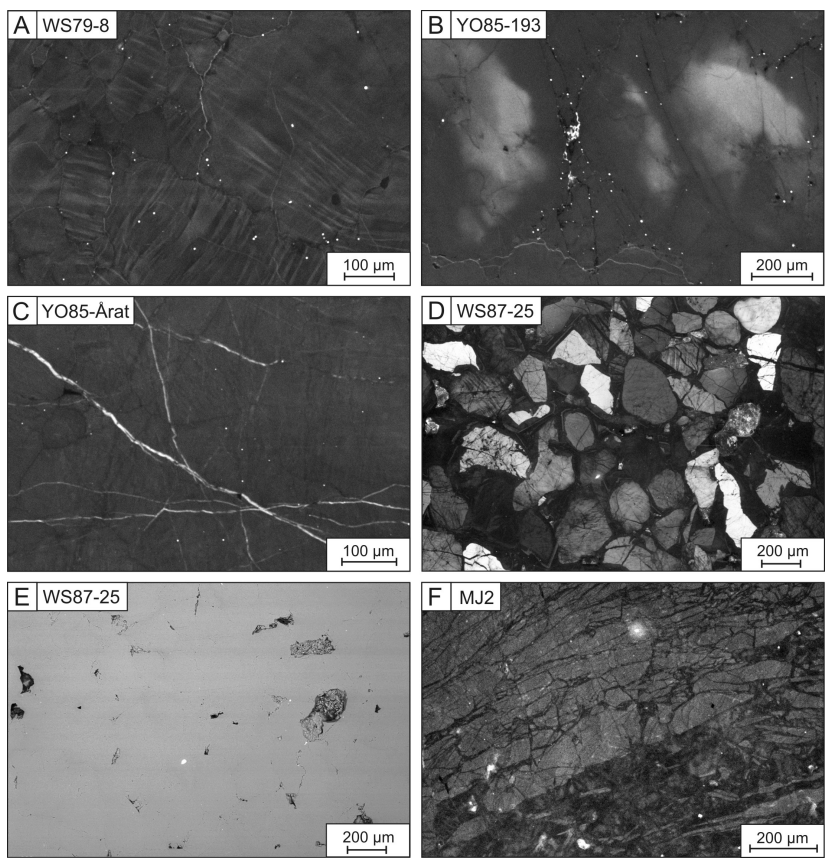

Fig. 8. SEM-CL and SEM images of quartz in onshore samples from Spitsbergen. (A) Distinctive lamella-like CL structures in quartz of the Proterozoic metagranite from Vestkysten. (B) Cloudy, bright luminescent domains in quartz with generally dull CL. Mesoproterozoic quartzite. (C) SEM-CL image of quartz with moderate CL intensity crosscut by thin $(<5 \mu \mathrm{m})$, healed micro-fractures with bright CL. (D) SEM-CL image of Permo-Carboniferous sandstone from the St. Jonsfjord. The majority of grains have bright CL and are overgrown by dull luminescent authigenic quartz. (E) BSE image of the same sample domain as shown in (D) illustrating that the interstitial areas of dark CL represent authigenic quartz. (F) SEMCL image of chert from the Permo-Carboniferous Gipsdalen Group at Billefjord. Fragments of moderate bright luminescent chert are healed by a silica generation with dull CL.

are regionally and genetically connected. The three types are recycled grains of immature sandstones, which originally were eroded from a low-grade metamorphic province with quartzite and low-temperature quartz segregation. Immature sandstones are common in the Mesozoic and Tertiary sedimentary successions of southeast and east Spitsbergen (Storfjord area, Barentsøya, Edgeøya and Hopen) (Dallmann, 1999). In fact, the quartz populations and their proportions identified in the Late Triassic sandstones of the De Geerdalen Formation from Edgeøya resemble closest the populations and their distributions found in most of the offshore samples. The similarities of the grain types occurring in the offshore samples and onshore samples from Edgeøya are astonishing as illustrated in Fig. 11. Thus, it is suggested that most of the IRD originate from these sediments which are exposed at Edgeøya, and Barentsøya and along the coast of inner Storfjorden covering an area of more than $3000 \mathrm{~km}^{2}$
(Fig. 1). In order to confirm this source area of the type A, B and $\mathrm{C}$ grains further, the ice drift will be considered below.

IRD of all grain sizes is transported predominantly by icebergs calved from the margins of tidewater glaciers, and to a much lesser extent by sea ice (Barnes et al., 1982; Nürnberg et al., 1994; Bischof, 2001). Icebergs and sea ice, and any included debris, drift under the action of ocean currents up to several hundred kilometres (Elverhøi et al., 1995; Hebbeln et al., 1998) and, to a lesser extent, wind. The drift ice melts and releases the debris, whereby coarser grained material ( $>500 \mu \mathrm{m}$ size fraction) falls directly to the sea floor. The transport of drift ice in the sampling area is controlled by the East Spitsbergen Current (ESC; e.g. Loeng, 1991; Fig. 1b). Entering the Barents Sea from the east/northeast, the ESC turns into Storfjord and continues encircling southern Spitsbergen where it flows northward along the continental shelf, passing Forlandsund and Prins Karls Forland. Occasionally westerly winds blow drift ice coming with the ESC in the inner parts of the fjords along the western coast, namely Hornsund, Van Mijenfjorden, Isfjord and Kongsfjord (Umbreit, 2009), implying that even the sample sites 1258 and 1265 might be affected by ESC drift ice. The major sources of icebergs in the catchment area of the ESC are fast moving (surging) tidewater glaciers on the east coast of Edgeøya and in inner Storfjord (Dowdeswell and Dowdeswell, 1997; Figs. 1b, 2). A number of smaller tidewater glaciers occur along the east coast of Spitsbergen between $77^{\circ}$ and $78^{\circ}$ N. However, calving icebergs hardly reach the west coast of Spitsbergen today. More important is the Storfjord area as the main producer of sea ice in southern Spitsbergen (Nilsen and Gammelsrød, 2008; Fig. 2). Sea ice is predominantly (>50\%) formed in open water areas. However, ca. $30 \%$ of the ice is produced as fast or pack ice (Haarpaintner et al., 2001) where sediments from the Edgeøya and Barentsøya can be incorporated and eventually transported via ESC towards the Spitsbergen west coast and further around the southern cape northward.

Thus, the most likely regional sources of the IRD for type $\mathrm{A}, \mathrm{B}$, and C are the east coast of Edgeøya and Barentsøya and inner Storfjord (Fig. 5). The dominant lithology in the catchment area of the tidewater glaciers comprises sediments of the Triassic Kapp Toscana Group and Sassendalen Group (Dallmann, 1999; Dallmann et al., 2002). The up to $400 \mathrm{~m}$ thick De Geerdalen Formation, part of the Kapp Toscana Group, is the most widespread sandstone-rich succession exposed in the suggested catchment areas of Edgeøya and inner Storfjorden. Summarizing, type A, B and C grains are recycled detrital grains of immature sandstone with sericiteFe-oxide/hydroxide coatings, which commonly occur in the Triassic De Geerdalen Formation at Edgeøya, Barentsøya, Hopen, and inner Storfjord, south Spitsbergen.

The type D grains are fragments of mature sandstones containing detrital grains of high-grade metamorphic and plutonic origins cemented by authigenic quartz. They are very different from the type $\mathrm{A}, \mathrm{B}$, and $\mathrm{C}$ grains. The fragments 

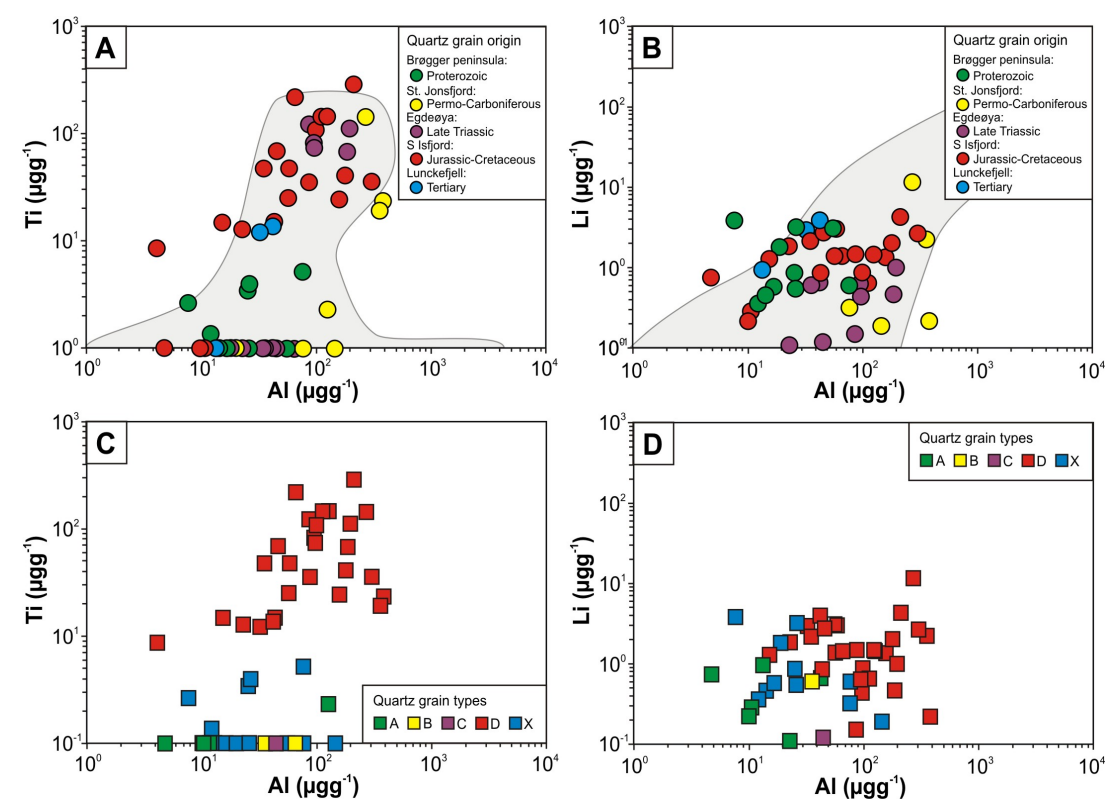

Fig. 9. Concentrations of $\mathrm{Al}$ versus $\mathrm{Ti}$ and $\mathrm{Li}$ of quartz grains in onshore samples. The same data are plotted, first, with respect to sample origin $(\mathbf{A}, \mathbf{B})$ and, second, to quartz type $(\mathbf{C}, \mathbf{D})$. In general, the concentrations plot in the same range as the offshore samples (grey shaded areas). (A, B) Samples from southern Isfjord are characterized by high Ti due to high proportion of D type grains (see C). (C, D) Type D grains have distinctively high Ti and relatively high average $\mathrm{Al}$ compared to the grain types $\mathrm{A}, \mathrm{B}, \mathrm{C}$, and $\mathrm{X}$. X type samples are quartz types which were not found in the offshore samples.

occur as minor constituents in the samples from Storfjord, Van Mijenfjorden, Forlandsund and Prins Karls Forland, but they are the major constituent in the sample from inner Isfjord. Thus, the type D grains in the Isfjord sample 1265 represent a local source (Fig. 5). Type D grains are the dominant grain population in sandstones of the Kapp Toscana and Adventdalen Group in the vicinity of the location of sample 1265. Tidewater glaciers of Tempelfjorden and - in historical times - Sassendal are the major source of drift ice in inner Isfjord (cf. Forwick and Vorren, 2009) (Fig. 1b). The rock units in the catchment area of these glaciers include sediments of these formations. The second, minor source of drift ice in Isfjord is the area of Storfjord from where ice is transported by the ESC around southern Spitsbergen and blown by common westerly winds into the inner parts of the Isfjord (Umbreit, 2009). Thus, type B grains in sample 1265, which form the minor population, are interpreted as IRD originating from the Triassic De Geerdalen Formation at Edgeøya, Barentsøya and inner Storfjord.

The type E arkose grains, which occur only in sample 1244 from inner Storfjord, are undoubtedly a local contribution from nearby onshore rocks. The sampling site is close to the mouth of the Agardhdalen and surging glaciers north and south of Agardhdalen. The sedimentary sequences around Agardhdalen comprise among others the Early Cretaceous Adventdalen Group (Dallmann et al., 1999). The investigated sandstone DH7A-1 of the Adventdalen Group is the only onshore sample in which type $\mathrm{E}$ grains were found
(Fig. 11). Exposures of the Adventdalen Group extend continuously from north Adventdalen, where the onshore sample was taken, to Agardhdalen at the western coast of Storfjord close to sample 1244 (Fig. 1). The sandstones of the Adventdalen Group occur in the glacier and river catchment areas in the Agardhdalen region close to the offshore sample (Fig. 1), and they are the likely source for type E grains found in sample 1244.

\section{Implications and conclusions}

The identification of geological provinces by means of IRDderived quartz grains $(>500 \mu \mathrm{m})$ in marine sediments off the Spitsbergen coast provides a new dimension in terms of reconstructing the dynamics and extent of past Spitsbergen/Barents Sea ice-sheet drainage basins. Traditionally, the configuration of the Weichselian ice sheets in the Spitsbergen/ Barents Sea region is reconstructed by combining evidence from terrestrial sediment and landforms with marine IRD records (cf. Svendsen et al., 2004). The intensity of IRD supply is thereby both indicative of the timing of maximal extent and break-up of the ice sheet (e.g. Elverhøi et al., 1995; Andersen et al., 1996; Knies et al., 2001; Jessen et al., 2010). Provenance studies on bulk material further constrain the sources of glacially eroded material, but can add little information on the regional dynamics of past ice sheet configurations (Bischof, 1994; Andersen et al., 1996; Vogt et al., 2001; Tütken et al., 2002; Moros et al., 2006; Andrews 


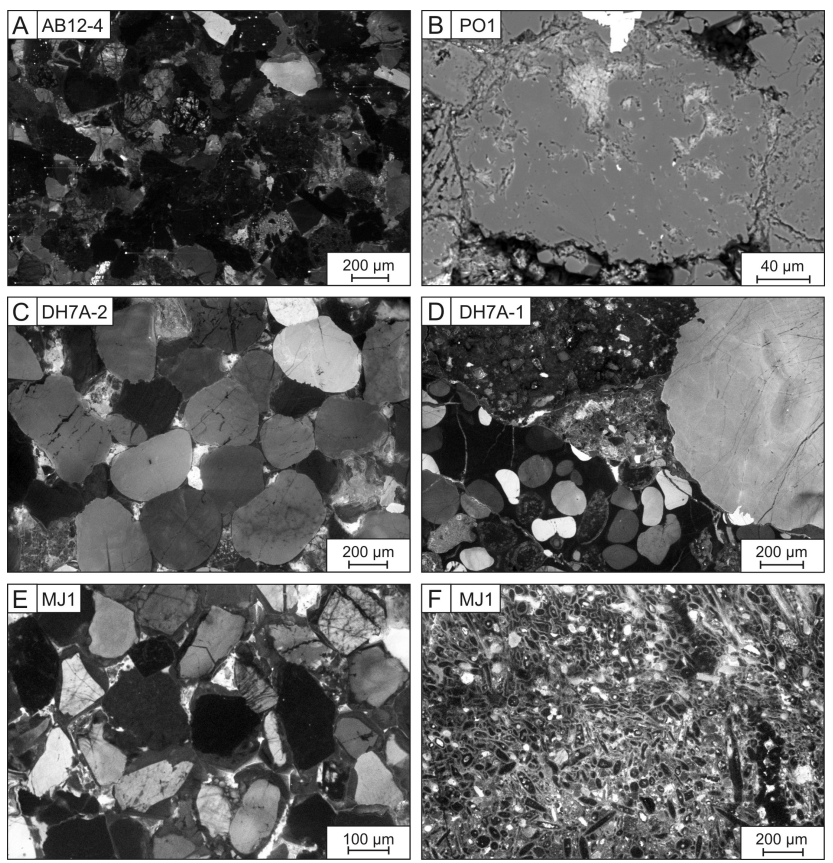

Fig. 10. SEM-CL and SEM images of quartz in onshore samples from Spitsbergen. (A) SEM-CL image of Late Triassic sandstone from Edgeøya. The sub-angular quartz grains have predominantly weak CL, are partially overgrown authigenic quartz and cemented by sericite. (B) BSE image of type B quartz grain of Late Triassic sandstone from Edgeøya with mica and feldspar micro-inclusions. (C) SEM-CL image of the Early Cretaceous sandstone from S Isfjord with predominantly bright luminescent quartz grains of type D. (D) SEM-CL image of two fragments of fine-grained arkose and one bright luminescent type D quartz grain in Early Cretaceous sandstone from S Isfjord. (E) SEM-CL image of the equigranular, medium-grained matrix of the Tertiary conglomerate from Lunckefjell. The predominantly bright luminescent grains are overgrown by authigenic quartz with dull CL. (F) SEM-CL image of a chert grain in sample MJ1 with distinctive structures.

et al., 2009). The latter may be inferred from the imagery of submarine landforms in the Barents Sea (Dowdeswell et al., 2010; Winsborrow et al., 2010), but configurations of previous glaciations remain unresolved unless applying 3-D seismic technology (Laberg et al., 2010).

Our data demonstrate that the descriptive CL characteristics of detrital quartz in combination with quantitative trace element determination by LA-ICP-MS provide a useful tool for the classification of the IRD grains into populations of distinctive provenance on Spitsbergen. Given a larger regional set of surface and downcore samples, this source-specific information from IRD-derived quartz grains may help to improve the reconstruction of ice-drainage patterns by identifying prominent zones of glacial erosion, not only during the late Weichselian but also possibly during previous glaciations. The next steps will be (1) collecting and analysing further onshore samples from Svalbard to ex-

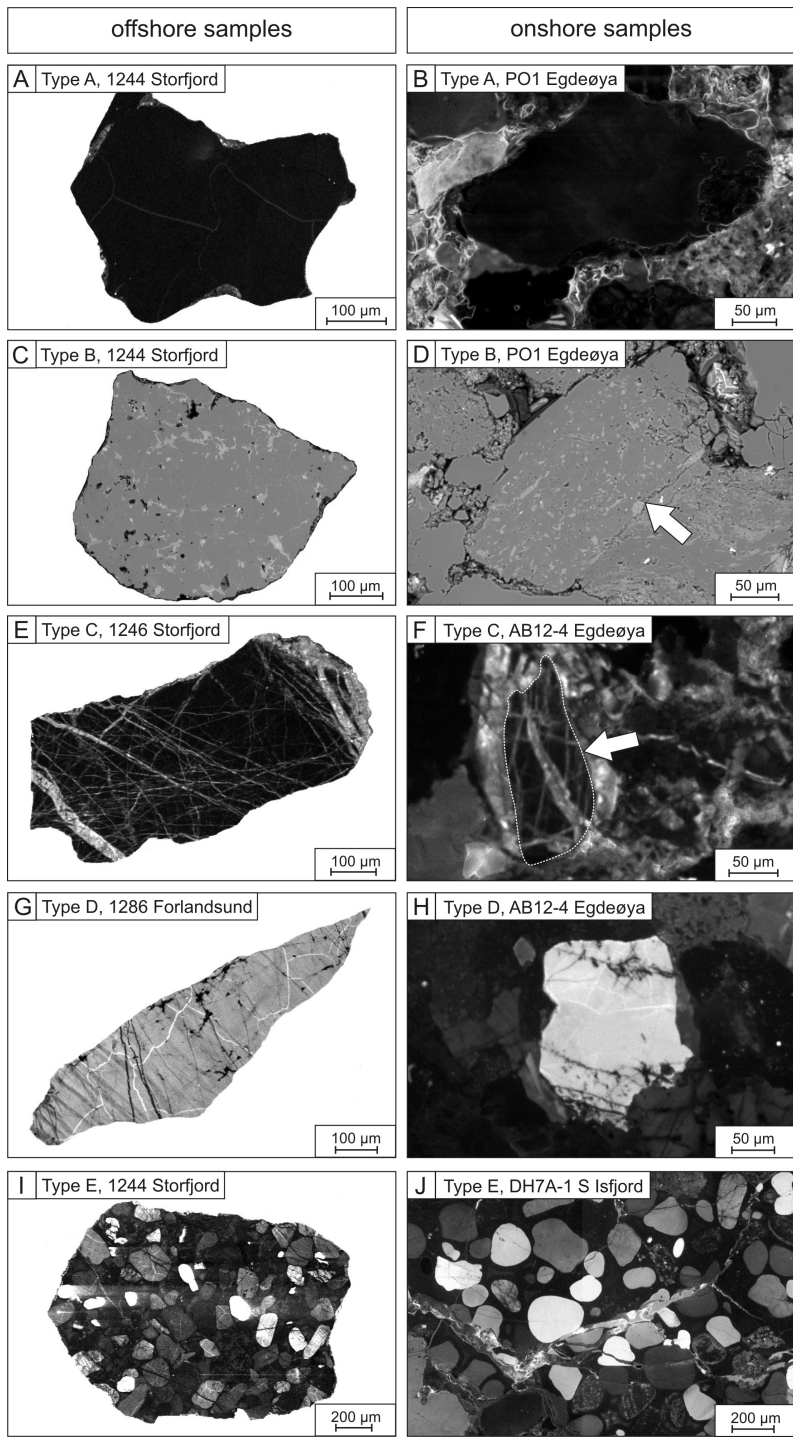

Fig. 11. SEM-CL and BSE images of quartz comparing grain types in offshore (left column) and onshore samples (right column). (A) SEM-CL image of a dull luminescent, featureless type A grain with sericitic remains at the grain edge (brighter areas). (B) SEM-CL image of a dull luminescent, featureless quartz grain of type A in Late Triassic sandstone from Edgeøya. (C) BSE image of a type B quartz grain with common mica and feldspar inclusions. (D) BSE image of a type B quartz grain (arrow) with common mica and feldspar inclusions in Late Triassic sandstone form the Edgeøya. (E) SEM-CL image of a type C grain from offshore sample 1246. (F) SEM-CL image showing a type $\mathrm{C}$ grain (arrow) in Late Triassic sandstone from the Edgeøya. (G) SEM-CL image of a bright luminescent type D grain from offshore sample 1286. (H) SEM-CL image of a bright luminescent type D grain in Late Triassic sandstone from the Edgeøya. (I) SEM-CL image of an arkose fragment (type E) from offshore sample 1244. (J) SEM-CL image of a large arkose fragment (type E) in Early Cretaceous sandstone from the southern Isfjord area. 
pand the database for further IRD provenance studies in this climate-sensitive region and (2) starting to analyse downcore records from the Yermak Plateau/western Svalbard margin, an area influenced by former palaeo-ice-streams (e.g. Gebhardt et al., 2011; Sarkar et al., 2011) and variable sea ice conditions (Fig. 2). On a longer term perspective, onshore samples from Greenland, Scandinavia and Iceland will be added to the database delineating major IRD provinces in the circum-North Atlantic-Arctic Ocean further.

So far, we have identified five distinct quartz grain populations (types A to E) in sediments off the Spitsbergen coast, indicative of potential IRD provinces in the Storfjord area.

The ubiquity of type A and B grains indicates a common regional source. They are recycled detrital grains of immature sandstone with sericite cement of a kind which commonly occurs in the Triassic De Geerdalen Formation on Edgeøy, Barentsøya, Hopen and in inner Storfjord. The less common type $\mathrm{C}$ grains are genetically related to type $\mathrm{A}$ and $\mathrm{B}$ grains. All three grain populations have been identified in onshore sandstones of the Late Triassic De Geerdalen Formation, which are likely the source of these quartz grains. Type $\mathrm{D}$ grains are fragments of mature, silicified, coarse-grained sandstones containing detrital quartz grains of primary highgrade metamorphic and plutonic origin. Type D grains form a minor constituent in a number of samples representing local sources that are presumably silicified mature sandstones. Type E grains occurring only in inner Storfjord are arkose fragments presumably originating from the Early Cretaceous Adventdalen Group.

The results imply that under modern (interglacial) conditions IRD deposition along the southern and western Spitsbergen margin is mainly governed by ESC-controlled ice drift patterns (mainly sea ice). The presence of detrital quartz from local provinces, however, indicates that variations in IRD supply from western and southern Spitsbergen may be quantified as well. In summary, applying this new IRD proxy on Arctic continental margin sediments will allow better definition of the sources of IRD and, thus, spatial and temporal changes of ice flow drainage patterns during glacial and deglacial periods.

\section{Supplementary material related to this article is available online at http://www.clim-past.net/9/2615/2013/ cp-9-2615-2013-supplement.pdf.}

Acknowledgements. We highly appreciate the logistic help of P. T. Osmundsen and J. S. Sandstad from the Geological Survey of Norway in Trondheim, S. Elvevold from the Norwegian Polar Institute in Troms $\emptyset$, and colleagues from the University Centre in Svalbard $\mathrm{CO}_{2}$ Lab AS and Store Norske Spitsbergen Grubekompani AS who provided the onshore samples from Spitsbergen and Edgeøya. We greatly appreciate improvement of the English text by R. Boyd. This research was partly supported by the Research Council of Norway through its Centers of Excellence funding schemes, project number 223259/F5.

Edited by: J. Giraudeau

\section{References}

Andersen, E. S., Dokken, T. M., Elverhøi, A., Solheim, and A., Fossen, I.: Late Quaternary sedimentation and glacial history of the western Svalbard continental margin, Mar. Geol., 133, 123-156, 1996.

Andrews, J. T., Darby, D., Eberle, D., Jennings, A. E., Moros, M., and Ogilvie, A.: A robust, multisite Holocene history of drift ice off northern Iceland: implications for North Atlantic climate, Holocene, 19, 71-77, 2009.

Andruleit, H., Freiwald, A., and Schafer, P.: Bioclastic carbonate sediments on the southwestern Svalbard shelf, Mar. Geol., 134, 163-182, 1996.

Barnes, P. W., Reimnitz, E., and Fox, D.: Ice rafting of finegrained sediment, a sorting and transport mechanism, Beaufort Sea, Alaska, J. Sediment. Petrol., 52, 493-502, 1982.

Bernet, M. and Bassett, K.: Provenance analysis by single-quartzgrain SEM-CL/optical microscopy, J. Sediment. Res., 75, 492500, 2005.

Bischof, J.: The decay of the Barents ice sheet as documented in nordic seas ice-rafted debris, Mar. Geol., 117, 35-55, 1994.

Bischof, J.: Ice drift, ocean circulation and climate change, Springer, Heidelberg, Germany, 2001.

Bjørlykke, K. and Elverhøi, A.: Reworking of Mesozoic clayey material in the north-western part of the Barents Sea, Mar. Geol., 18, M29-M34, 1975.

Bond, G., Showers, W., Cheseby, M., Lotti, R., Almasi, P., deMenocal, P., Priore, P., Cullen, H., Hajdas, I., and Bonani, G.: A pervasive millennial-scale cycle in North Atlantic Holocene and glacial climates, Science, 278, 1257-1266, 1997.

Bond, G., Kromer, B., Beer, J., Muscheler, R., Evans, M. N., Showers, W., Hoffmann, S., Lotti-Bond, R., H., Hajdas, I., and Bonani, G.: Persistent solar influence on north Atlantic climate during the Holocene, Science, 294, 2130-2136, 2001.

Dallmann, W. K. (Ed.): Lithostratigraphic lexicon of Svalbard. Review and recommendations for nomenclature use. Late Palaeozoic to Quaternary Bedrock, Norwegian Polar Institute, Norway, 1999.

Dallmann, W. K., Ohta, Y., Elvevold, S., and Blomeier, D. (Eds.): Bedrock map of Svalbard and Jan Mayen, Norsk Polarinstitutt Temakart No. 33, 2002.

Darby, D. A., Bischof, J. F., Spielhagen, R. F., Marshall, S. A., and Herman, S. W.: Arctic ice export events and their potential impact on global climate during the late Pleistocene, Paleoceanography, 17, 1025, doi:10.1029/2001PA000639, 2002.

Dibner, V. D., Basov, V. A., Gerke, A. A., Solovyeva, M. F., Sisopatrova, G. P., and Shulgina, N. I.: The age of the re-Quaternary deposits on the bottom of the Barents Sea, Oceanology, 10, 520529, 1970.

Dowdeswell, J. A. and Dowdeswell, E. K.: Modern glaciers and climate change, in: Geology of Svalbard: Geol. Soc. Memoir, edited by: Harland, W. B., 17, 436-445, 1997. 
Dowdeswell, J. A., Hogan, K. A., Evans, J., Noormets, R., Cofaigh, C. Ó., and Ottesen, D.: Past ice-sheet flow east of Svalbard inferred from streamlined subglacial landforms, Geology, 38, 163166,2010

Elverhøi, A., Andersen, E. S., Dokken, T., Hebbeln, D., Spielhagen, R., Svendsen, J. I., Sorflaten, M., Rornes, A., Hald, M., and Forsberg, C. F.: The growth and decay of the late weichselian ice sheet in western Svalbard and adjacent areas based on provenance studies of marine sediments, Quaternary Res., 44, 303316, 1995.

Farmer, L. G., Barber, D., and Andrews, J.: Provenance of Late Quaternary ice-proximal sediments in the North Atlantic: $\mathrm{Nd}, \mathrm{Sr}$ and $\mathrm{Pb}$ isotopic evidence, Earth Planet. Sc. Lett., 209, 227-243, 2003.

Flem, B. and Müller, A.: In situ analysis of trace elements in quartz using laser ablation inductively coupled plasma mass spectrometry, in: Quartz: Deposits, mineralogy and analytics, edited by: Götze, J. and Möckel, R., Springer, Berlin, Heidelberg, Germany, 219-236, doi:10.1007/978-3-642-22161-3_10, 2012.

Flem, B., Larsen, R. B., Grimstvedt, A., and Mansfeld, J.: In situ analysis of trace elements in quartz by using laser ablation inductively coupled plasma mass spectrometry, Chem. Geol., 182, 237-247, doi:10.1016/S0009-2541(01)00292-3, 2002.

Forwick, M. and Vorren, T. O.: Late Weichselian and Holocene sedimentary environments and ice rafting in Isfjorden, Spitsbergen, Palaeogeogr. Palaeocl., 280, 258-274, 2009.

Forwick, M., Vorren, T. O., Hald, M., Korsun, S., Roh, Y., Vogt, C., and Yoo, K. C.: Spatial and temporal influence of glaciers and rivers on the sedimentary environment in Sassenfjorden and Tempelfjorden, Spitsbergen, in: Fjord Systems and Archives edited by: Howe, J. A., Austin, W. E. N., Forwick, M., and Paetzel, M., Geol. Soc. Special Publ., London, 344, 163-193, 2010.

Gebhardt, A. C., Jokat, W., Niessen, F., Matthiessen, J., Geissler, W. H., and Schenke, H. W.: Ice sheet grounding and iceberg plow marks on the northern and central Yermak Plateau revealed by geophysical data, Quaternary Sci. Rev., 30, 1726-1738, 2011.

Götze, J.: Chemistry, textures and physical properties of quartz - geological interpretation and technical application, Mineral. Mag., 73, 645-671, doi:10.1180/minmag.2009.073.4.645, 2009.

Götze, J. and Zimmerle, W.: Quartz and silica as guide to provenance in sediments and sedimentary rocks, Contr. Sediment. Geol., 21, Schweizerbart'sche Verlagsbuchhandlung, Stuttgart, Germany, 2000.

Grousset, F. E., Labeyrie, L., Sinko, J. A., Cremer, M., Bond, G., Duprat, J., Cortijo, E., and Huon, S.: Patterns of ice-rafted detritus in the glacial north Atlantic $\left(40-55^{\circ} \mathrm{N}\right)$ : Paleoceanography, 8, 175-192, 1993.

Haarpaintner, J., Gascard, J. C., and Haugan, P. M.: Ice production and brine formation in Storfjorden, Svalbard, J. Geophys. Res.Oceans, 106, 14001-14013, 2001

Hebbeln, D., Dokken, T., Andersen, E. S., Hald, M., and Elverhøi, A.: Moisture supply for northern ice-sheet growth during the Last Glacial Maximum, Nature, 350, 409-411, 1994.

Hebbeln, D., Henrich, R., and Baumann, K. H.: Paleoceanography of the last interglacial/glacial cycle in the Polar North Atlantic, Quaternary Sci. Rev., 17, 125-153, 1998.

Hemming, S. R.: Heinrich events: Massive late Pleistocene detritus layers of the North Atlantic and their global climate imprint, Rev. Geophys., 42, RG1005, doi:10.1029/2003RG000128, 2004.
Jessen, S. P., Rasmussen, T. L., Nielsen, T., and Solheim, A.: A new Late Weichselian and Holocene marine chronology for the western Svalbard slope 30,000-0 cal years BP, Quaternary Sci. Rev., 29, 1301-1312, 2010.

Jourdan, A.-L., Vennemann, T. W., Mullis, J., Ramseyer, K., and Spiers, C. J.: Evidence of growth and sector zoning in hydrothermal quartz from Alpine veins, Eur. J. Mineral., 21, 219-231, 2009.

Knies, J., Kleiber, H. P., Matthiessen, J., Muller, C., and Nowaczyk, N.: Marine ice-rafted debris records constrain maximum extent of Saalian and Weichselian ice-sheets along the northern Eurasian margin, Global Planet. Change, 31, 45-64, 2001.

Kolla, V., Biscaye, P. E., and Hanley, A. F.: Distribution of quartz in Late Quaternary sediments in relation to climate, Quaternary Res., 11, 261-277, 1979.

Laberg, J. S., Andreassen, K., Knies, J., Vorren, T. O., and Winsborrow, M.: Late Pliocene-Pleistocene development of the Barents Sea Ice Sheet, Geology, 38, 107-110, 2010.

Loeng, H.: Features of the physical oceanographic conditions of the Barents Sea, Polar Res., 10, 5-18, 1991.

Michelsen, J. K. and Khorasani, G. K.: A regional study on coals from Svalbard: organic facies, maturity and thermal history, B. Soc. Geol. Fr., 162, 385-397, 1991.

Moros, M., Andrews, J. T., Eberl, D. D., and Jansen, E.: Holocene history of drift ice in the northern North Atlantic: Evidence for different spatial and temporal modes, Paleoceanography, 21, PA2017, doi:10.1029/2005PA001214, 2006.

Nilsen, F. and Gammelsrød, T.: Large sea ice production affects the climate? The University Centre in Svalbard News, available at: http://www.unis.no/60_NEWS/6040_Archive_2008/n_08_06_ 04_storfjorden/Storfjorden_news_04062008.htm (last access: 8 November 2008), 2008.

Nürnberg, D., Wolkenburg, I., Dethleff, D., Eicken, H., Kassens, H., Letzig, T., Reimnitz, E., and Thiede, J.: Sediments in Arctic sea ice: Implications for entrainment, transport and release, Mar. Geol., 119, 185-214, 1994.

Peck, V. L., Halla, I. R., Zahn, R., Grousset, F., Hemming, S. R., and Scourse, J. D.: The relationship of Heinrich events and their European precursors over the past $60 \mathrm{ka} \mathrm{BP}$ : a multi-proxy icerafted debris provenance study in the North East Atlantic, Quaternary Sci. Rev., 26, 862-875, 2007.

Sarkar, S., Berndt, C., Chabert, A., Masson, D. G., Minshull, T. A., and Westbrook, G. K.: Switching of a paleo-ice stream in northwest Svalbard, Quaternary Sci. Rev., 30, 1710-1725, 2011.

Schlichtholz, P. and Goszczko, I.: Interannual variability of the Atlantic water layer in the West Spitsbergen Current at $76,5^{\circ} \mathrm{N}$ in summer 1991-2003, Deep-Sea Res., 53, 608-626, 2006.

Seyedolali, A., Krinsley D. H., Boggs, S., O’Hara, P. F., Dypvik, H., and Goles, G. G.: Provenance interpretation of quartz by scanning electron microscope - cathodoluminescence fabric analysis, Geology, 25, 787-790, 1997.

Skogseth, R.: Dense water production processes in Storfjorden. Report No. 2-2003, University Center on Svalbard, Longyearbyen, Norway, 2003.

Steel, R. J. and Worsley, D.: Svalbard's post-Caledonian strata: an atlas of sedimentational patterns and palaeogeographic evolution, in: Petroleum geology of the North European Margin, edited by: Spencer, A. M., Holter, E., Johnsen, S. O., Mørk, A., 
Nysæther, E., Songstad, P., and Spinnangr, Å., Graham and Trotman, London, UK, 109-135, 1984.

Stein, R.: Arctic Ocean Sediments. Processes, Proxies, and Paleoenvironment, Developments in Marine Geology Vol. 2, Elsevier, Amsterdam, 2008.

Sundvor, E.: Seismic refraction and reflection measurements in the southern Barents Sea, Mar. Geol., 16, 255-273, 1974.

Svendsen, J. I., Alexanderson, H., Astakhov, V. I., Demidov, I., Dowdeswell, J. A., Funder, S., Gataullin, V., Henriksen, M., Hjort, C., Houmark-Nielsen, M., Hubberten, H. W., Ingolfsson, O., Jakobsson, M., Kjaer, K. H., Larsen, E., Lokrantz, H., Lunkka, J. P., Lysa, A., Mangerud, J., Matiouchkov, A., Murray, A., Moller, P., Niessen, F., Nikolskaya, O., Polyak, L., Saarnisto, M., Siegert, C., Siegert, M. J., Spielhagen, R. F., and Stein, R.: Late quaternary ice sheet history of northern Eurasia, Quaternary Sci. Rev., 23, 1229-1271, 2004.

Tütken, T., Eisenhauer, A., Wiegand, B., and Hansen, B. T.: Glacialinterglacial cycles in $\mathrm{Sr}$ and $\mathrm{Nd}$ isotopic composition of Arctic marine sediments triggered by the Svalbard/Barents Sea ice sheet, Mar. Geol., 182, 351-372, 2002.

Umbreit, A.: Spitzbergen, Conrad Stein Verlag, Kiel, Germany, 2009.

Verplanck, E. V., Lang Farmer, G., Andrews, J., Gita Dunhill, G., and Millo, C.: Provenance of Quaternary glacial and glacimarine sediments along the southeast Greenland margin, Earth Planet. Sc. Lett., 286, 52-62, 2009.
Vogt, C., Knies, J., Spielhagen, R. F., and Stein, R.: Detailed mineralogical evidence for two nearly identical glacial/deglacial cycles and Atlantic water advection to the Arctic Ocean during the last 90,000 years, Global Planet. Change, 31, 23-44, 2001.

Wark, D. A. and Watson, E. B.: TitaniQ: a titanium-in-quartz geothermometer, Contrib. Mineral. Petr., 152, 743-754, 2006.

Winkelmann, D.: Reconstruction of recent and late Holocene sedimentation processes on the continental shelf west off Spitsbergen. Diploma Thesis, Freiberg University of Mining and Technology, Germany, 2003.

Winkelmann, D. and Knies, J.: Recent distribution and accumulation of organic carbon on the continental margin west off Spitsbergen, Geochem. Geophy. Geosy., 6, Q09012, doi:10.1029/2005GC000916, 2005.

Winsborrow, M. C. M., Andreassen, K., Corner, G. D., and Laberg, J. S.: Deglaciation of a marine-based ice sheet: Late Weichselian palaeo-ice dynamics and retreat in the southern Barents Sea reconstructed from onshore and offshore glacial geomorphology, Quaternary Sci. Rev., 29, 424-442, 2010. 